\title{
IMPLEMENTASI PERMENAG NOMOR 2 TAHUN 2008 DAN PERMENDIKBUD NOMOR 20 TAHUN 2016 TENTANG STANDAR KOMPETENSI LULUSAN DI MAN PRAMBON NGANJUK
}

\author{
Novita Rahmah \\ Madrasah Ibtidaiyah Negeri 8 Nganjuk
}

\begin{abstract}
Abstrak.
Implementasi Permenag Nomor 2 Tahun 2008 dan Permendikbud Nomor 20 Tahun 2016 Tentang Standar Kompetensi Lulusan perlu dikuatkan dalam pelaksanaan di lapangan karena ditengarai di MAN Prambon muncul permasalahan pedagogik guru yang belum maksimal, sarana dan prasarana pembelajaran yang belum lengkap, input siswa kurang berkualitas, sebagian tamatan SMP kurang mampu mempelajari Mapel Bahasa Arab. Minat, motivasi dan disiplin belajar siswa kurang maksimal, dan belum maksimalnya pos-pos pembiayaan untuk kegiatan pembelajaran dan kegiatan ekstra kurikuler serta pembiayaan kegiatan pengembangan diri karena minimnya sumber pendapatan. Kesimpulan penelitian ini adalah: 1) Bentuk Implementasi Permenag No. 2 Tahun 2008 dan Permendikbud Nomor 20 tahun 2016 tentang Standar Kompetensi Lulusan di MAN Prambon Nganjuk bagi guru PAI dan Bahasa Arab adalah berikut: a) Guru melaksanakan kegiatan pembelajaran dengan menerapkan strategi dan metode mengajar yang sesuai, mengadakan penilaian dan analisis hasil belajar, serta evaluasi, mengadakan program remidi dan pengayaan, b) Pengadaan tes peminatan pada siwa baru untuk penempatan jurusan. 2) Implikasi Implementasi Permenagsebagai berikut: a) Implikasinya didasarkan pada pada tujuan pendidikan nasional, b) didasarkan pada ruang lingkup standar kompetensi lulusan, c) dilakukan dengan cara mengadakan monitoring dan evaluasi, d) dilaksanakan berdasar kebijakan kepala madrasah, e) dijalankan dengan baik sesuai dengan rencana. 3) Faktor-faktor Pendukung antara lain: a) Kondisi riil standar isi yang bagusdan Respon komite dan siswa sangat baik. Sedangkan faktor-faktor penghambatnya antara lain: fasilitas untuk memenuhi terlaksnanya kurikulum 13 sangat terbatas.
\end{abstract}

Kata Kunci : Implementasi Permenag Nomor 2 Tahun 2008 dan Permendikbud Nomor 20 Tahun 2016 Tentang Standar Kompetensi Lulusan.

\section{Pendahuluan}

Implementasi Permenag Nomor 2 Tahun 2008 dan Permendikbud Nomor 20 Tahun 2016 Tentang Standar Kompetensi Lulusan perlu dikuatkan dalam pelaksanaan di lapangan karena ditengarai di MAN Prambon muncul permasalahan pedagogik guru yang belum maksimal, sarana dan prasarana pembelajaran yang belum lengkap, input siswa kurang berkualitas, sebagian tamatan SMP kurang mampu mempelajari Mapel Bahasa Arab. Minat, motivasi dan disiplin belajar siswa kurang maksimal, dan belum maksimalnya pos-pos pembiayaan untuk kegiatan pembelajaran dan kegiatan ekstra kurikuler serta pembiayaan kegiatan pengembangan diri karena minimnya sumber pendapatan.

Dasar, fungsi, dan tujuan pendidikan nasional menurut Undang-Undang Republik Indonesia Nomor 20 Tahun 2003 tentang Sistem Pendidikan Nasional bahwa pendidikan nasional berdasarkan Pancasila dan Undang-Undang Dasar Negara Republik Indonesia Tahun 1945 (Pasal 2), berfungsi mengembangkan kemampuan dan membentuk watak serta peradaban bangsa yang bermartabat dalam rangka mencerdaskan kehidupan bangsa, bertujuan untuk mengembangkan potensi peserta didik agar menjadi manusia yang beriman dan bertakwa kepada Tuhan Yang Maha Esa, berakhlak mulia, sehat, berilmu, 
cakap, kreatif, mandiri, dan menjadi warga negara yang demokratis serta bertanggung jawab (Pasal 3).

Pemberlakuan Undang-Undang

Nomor 20 Tahun 2003 tentang Sistem Pendidikan Nasional merupakan tonggak baru bagi perkembangan lembaga pendidikan Islam, di mana lembaga pendidikan Islam di setiap jenjangnya (MI, MTs, dan MA) sudah disejajarkan dengan jenjang pendidikan sekolah formal nasional dan bahkan sudah disebutkan secara bersama-sama, sehingga tidak ada perbedaan yang berarti terhadap kualitas proses dan hasil pembelajaran serta mutu lulusan antara pendidikan yang dilaksanakan di lembaga pendidikan Islam dan pendidikan sekolah formal.

Berdasarkan pemikiran di atas dapat dikatakakan bahwa keberhasilan implementasi Permenag Nomor 2 Tahun 2008 tentang Standar Kompetensi Lulusan PAI dan Bahasa Arab serta Permendikbud Nomor 20 tahun 2016 tentang Standar Kompetensi Lulusan Pendidikan Dasar dan Menengah di Madrasah sangat tergantung dari keseluruhan Lingkup Standar Nasional Pendidikan. Padahal tidak semua madrasah mampu memenuhi dengan baik seluruh lingkup standar pendidikan nasional, permasalahan ini juga dialami oleh MAN Prambon Nganjuk, apalagi permasalahan perubahan kurikulum dari KTSP menjadi K-13 yang harus dilaksanakan secara bersamaan di madrasah.

Sebagaimana telah diatur dalam Peraturan menteri Pendidikan Dan Kebudayaan Republik Indonesia nomor 160 tahun 2014, tentang pemberlakuan kurikulum tahun 2006 dan kurikulum 2013. Disebutkan pada pasal 1; Satuan Pendidikan dasar dan Pendidikan menengah yang melaksanakan Kurikulum 2013 sejak semester pertama, tahun pelajaran 2014/2015, kembali melaksanakan Kurikulum Tahun 2006 mulai semester kedua tahun pelajaran 2014/ 2015 sampai ada ketetapan dari
Kementerian untuk melaksanakan Kurikulum 2013.1

Sebagai tindak lanjut pelaksanaan Peraturan Menteri Pendidikan Dan Kebudayaan Republik Indonesia nomor 160 tahun 2014, maka diterbitkan Keputusan Menteri Agama Republik Indonesia, Nomor 207 tahun 2014 tentang Kurikulum Madrasah. Berdasarkan peraturan tersebut, Madrasah Aliyah diluar sasaran pendampingan, harus kembali menerapkan kurikulum 2006 (KTSP) untuk mata pelajaran umum dan tetap menerapkan Kurikulum Madrasah 2013 (KURMA 13) untuk mata pelajaran PAI dan bahasa Arab dengan penyesuaian pada Struktur Kurikulum, Standar Proses dan Standar Penilaian yang akan dijelaskan lebih rinci pada pedoman khusus. Namun demikian perubahan kurikulum tersebut menjadikan proses pembelajaran belum maksimal karena adanya perubahanperubahan dan perbaikan-perbaikan kurikulum, termasuk juga tentang Standar kompetensi lulu-san.

Sementara itu berdasarkan penelitian terdahulu ditemukan berbagai permasalahan yang dihadapi oleh madrasah sehubungan dengan implementasi standar kompetensi lulusan sebagai berikut:

Standar isi: kurikulum (KTSP) dan K13 belum mampu dilaksanakan secara maksimal karena kedalaman muatan kurikulum yang dituangkan dalam kompetensi (standar kompetensi dan kompetensi dasar) pada setiap tingkat dan/atau semester, beban belajar, jam pembelajaran, waktu efektif tatap muka, dan persentase beban belajar setiap kelompok mata pelajaran belum sepenuhnya dapat dilaksanakan sesuai dengan rencana.

Standar proses: proses pembelajaran belum sepenuhnya diselenggarakan secara interaktif, inspiratif, menyenangkan, dan menantang, serta belum maksimalnya

1 Kementrian Agama RI., Pedoman Teknis (Domnis) Implementasi Kurikulum Madrasah Mata Pelajaran PAI Dan Bahasa Arab Pada Madrasah Ibtidaiyah, Madrasah Tsanawiyah Dan Madrasah Aliyah, (Jakarta: Kemenag RI, 2015), hlm. 14. 
peran motivasi bagi peserta didik untuk berpartisipasi aktif dalam pembelajaran, karena metode pembelajaran yang diterapkan guru tidak semuanya menerapkan metode kooperatif (Paikemi: pembelajaran yang aktif, inovatif, kreatif, efektif dan menyenangkan serta islami), belum maksimalnya perencanaan pembelajaran, pelaksanaan pembelajaran, penilaian hasil pembelajaran, dan pengawasan proses pembelajaran untuk terlaksananya proses pembelajaran yang efektif dan efi-sien.

Standar pendidik: kualifikasi akademik yang dibuktikan dengan ijazah dan/atau sertifikat keahlian belum semuanya relevan sesuai ketentuan perundang-undangan yang berlaku, dan kompetensi guru sebagai agen pembelajaran yang meliputi kompetensi pedagogik; kompetensi kepribadian; kompetensi profesional; dan kompetensi sosial belum maksimal.

Standar sarana dan prasarana: sarana terutama perabot, peralatan pendidikan, media pendidikan, buku dan sumber belajar lainnya, belum terpenuhi dengan baik dan belum maksimal, prasarana terutama lahan, ruang kelas, ruang pendidik, ruang tata usaha, ruang perpustakaan, ruang laboratorium, tempat berolahraga, tempat beribadah, tempat bermain, tempat berkreasi, dan ruang/ tempat lain yang diperlukan untuk menunjang proses pembelajaran yang teratur dan berkelanjutan belum terpenuhi dengan baik dan belum maksimal.

Standar pengelolaan oleh satuan pendidikan: pengelolaan pendidikan belum sepenuhnya menerapkan manajemen berbasis sekolah yang ditunjukkan dengan kemandirian, kemitraan, partisipasi, keterbukaan, dan akuntabilitas.

Standar pembiayaan: biaya investasi, yakni biaya penyediaan sarana dan prasarana, pengembangan sumberdaya manusia, dan modal kerja tetap belum maksimal, biaya operasi yakni biaya operasi pendidikan tak langsung berupa daya listrik, pemeliharaan sarana dan prasarana belum maksimal dan belum terpenuhi dengan baik, dan biaya personal yakni biaya pendidikan yang harus dikeluarkan oleh peserta didik untuk bisa mengikuti proses pembelajaran secara teratur dan berkelanjutan cukup mahal.

Stándar penilaian pendidikan: penilaian hasil belajar oleh pendidik belum maksimal karena belum semua guru menilai pencapaian kompetensi peserta didik yang sebenarnya, tidak semua guru mempunyai bank soal, tidak semua guru melaksanakan program perbaikan dan pengayaan, dan penilaian hasil belajar tidak sepenuhnya digunakan untuk memperbaiki proses pembelajaran (aktivitas guru dan aktivitas siswa) tetapi cenderung kepada hasil pembelajaran dari sisi siswa saja ${ }^{2}$.

Berdasar pendapat permasalahan tersebut, berarti seluruh komponen pendidikan di madrasah (kepala madrasah, guru, dan tenaga kependidikan lainnya) memegang peranan yang penting dalam keberhasilan pendidikan. Dipundak mereka terpikul tanggungjawab utama keefektifan seluruh usaha kependidikan persekolahan. ${ }^{3}$ Tanggungjawab utama mereka dalam hal ini dapat dikaitkan dengan tang-gungjawabnya dalam mengimplementasikan dan Permenag Nomor 2 Tahun 2008 dan Permendikbud Nomor 20 tahun 2016 tentang Standar Kompetensi Lulusan Pendidikan Dasar dan Menengah Standar Kompetensi Lulusan dan Standar Isi Pendidikan Agama Islam Dan Bahasa Arab di Madrasah.

Oleh karena fokus penelitian ini tertuju pada standar kompetensi lulusan yang mempunyai relevansi dengan kedua permen tersebut, maka terdorong keinginan peneliti untuk mengadakan studi

2 Masykur. Implementasi Permendikbud Nomor 23 Tahun 2006 dan Permenag Nomor 2 Tahun 2008 Tentang Standar Kompetensi Lulusan di MAN Nglawak Kertosono Nganjuk. (Tesis Unipdu Jombang, 2012), hlm. 6-8.

3 Tim Direktorat Jenderal Pembinaan Kelembagaan Agama Islam/Direktorat Pembinaan Pendidikan Agama Islam pada Sekolah Umum, Metodologi Pendidikan Agama Islam, (Jakarta: Direktorat Jenderal Pembinaan Kelembagaan Agama Islam/Direktorat Pembinaan Pendidikan Agama Islam pada Sekolah Umum melalui Bagian Proyek Peningkatan Tenaga Teknis Pendidikan Agama Islam, 2011), hlm. 1. 
secara mendalam dengan memfokuskan masalah pada: Implementasi Permenag No. 2 Tahun 2008 dan Permendikbud Nomor 20 tahun 2016 tentang Standar Kompetensi Lulusan di MAN Prambon Nganjuk.

Berpijak pada latar belakang masalah di atas, maka fokus penelitian ini dapat dikemukakan berikut: 1). Bagaimanakah bentuk implementasi Permenag No. 2 Tahun 2008 dan Permendikbud Nomor 20 tahun 2016 tentang Standar Kompetensi Lulusan di MAN Prambon Nganjuk (yang mengacu pada Standar Nasional Pendidikan dan Permenag No. 2 Tahun 2008 bagi guru PAI dan Bahasa Arab)?; 2) Bagaimanakah implikasi dari implementasi Permenag No. 2 Tahun 2008 dan Permendikbud Nomor 20 tahun 2016 tentang Standar Kompetensi Lulusan di MAN Prambon Nganjuk?; 3) Apa sajakah faktor-faktor Pendukung dan Penghambat Implementasi Permenag No. 2 Tahun 2008 dan Permendikbud Nomor 20 tahun 2016 Tentang Standar Kompetensi Lulusan di MAN Prambon Nganjuk?

\section{Standar Kompetensi Lulusan}

Berdasarkan Peraturan Pemerintah Nomor 20 Tahun 2016 tentang Standar Kompetensi Lulusan (SKL) Pendidikan Dasar dan Menengah dijelaskan sebagai berikut: "Standar kompetensi lulusan adalah kriteria mengenai kualifikasi kemampuan lulusan yang mencakup sikap, pengetahuan, dan keterampilan.", selanjutnya pasal 1 ayat 1-3.

Dalam prakteknya kriteria mengenai kualifikasi kemampuan lulusan yang mencakup sikap, pengetahuan, dan keterampilan siswa sangat bervariasi, karena perbedaan karakteristik individu dan sosial siswa. Dalam dunia pembelajaran perbedaan tersebut tampak pada perbedaan aspek kognitif, aspek afektif dan aspek psikomotor.

Dalam Permendikbud Nomor 20 tahun 2016 tentang Standar Kompetensi Lulusan dijelaskan bahwa tujuan standar

4Permendikbud Nomor 23 Tahun 2016 tentang Standar ..., hlm. 3. kompetensi lulusan digunakan sebagai "acuan utama pengembangan standar isi, standar proses, standar penilaian pendidikan, standar pendidik dan tenaga kependidikan, standar sarana dan prasarana, standar pengelolaan, dan standar pembiayaan". Sementara itu ruang lingkup standar kompetensi lulusan terdiri atas "kriteria kualifikasi kemampuan peserta didik yang diharapkan dapat dicapai setelah menyelesaikan masa belajarnya di satuan pendidikan pada jenjang pendidikan dasar dan menengah". ${ }^{5}$

Kualifikasi kemampuan peserta didik dapat diketahui setelah mereka menyelesaikan masa belajarnya di madrasah, ketercapaian keberhasilan tersebut selalu dihubungkan dengan empat kompetensi, yaitu (1) kompetensi sikap spiritual, (2) sikap sosial, (3) pengetahuan, dan (4) keterampilan. Kompetensi tersebut dica-pai melalui proses pembelajaran intrakurikuler, kokurikuler, dan/atau ekstrakuri-kuler. Oleh karena itu agar siswa mampu mencapai standar kompetensi lulusan yang telah ditetapkan oleh madrasah dan pemerintah, semua stake holder harus bekerja secara maksimal sesuai dengan bidang tugasnya dalam upaya mengimplementasikan Permenag Nomor 2 Tahun 2008 dan Permendikbid Nomor 20 Tahun 2016 tentang Standar Kom-petensi Lulusan (SKL) Pendidikan Dasar dan Menengah tentang Standar Kompetensi Lulusan.

Dalam Permendikbud Nomor 20 tahun 2016 tentang Standar kompetensi lulusan dijelaskan bahwa:

Untuk mengetahui ketercapaian dan kesesuaian antara Standar Kompetensi Lulusan dan lulusan dari masing-masing satuan pendidikan dan kurikulum yang digunakan pada satuan pendidikan tertentu perlu dilakukan monitoring dan evaluasi secara berkala dan berkelanjutan dalam setiap periode. Hasil yang diperoleh dari monitoring dan evaluasi digunakan sebagai bahan masukan bagi

5 Permendikbud Nomor 20 tahun 2016 tentang Standar ... hlm. 2-3 
penyempurnaan Standar Kompetensi Lulusan di masa yang akan datang. ${ }^{6}$

Secara tradisional pelaksanaan monitoring melibatkan tahapan: (a) menetapkan standar untuk mengukur prestasi, (b) mengukur prestasi, (c) menganalisis apakah prestasi memenuhi standar, dan (d) mengambil tindakan apabila prestasi kurang/tidak memenuhi standar7.

Dalam perkembangan terakhir, kecenderungan monitoring dalam dunia pendidikan juga mengikuti apa yang dilakukan pada industri, yaitu dengan menerapakan Total Quality Controll. Pengawasan ini tentu saja terfokus pada pengendalian mutu dan lebih bersifat internal. Oleh karena itu pada akhir-akhir ini setiap lembaga pendidikan umumnya memiliki unit penjaminan mutu.

Kegiatan evaluasi ditujukan untuk mengetahui sejauhmana kesuksesan pelaksanaan penyelenggaraan sekolah atau sejauhmana keberhasilan yang telah dicapai dalam kurun waktu tertentu. Tujuan evaluasi utamanya adalah untuk (a) mengetahui tingkat keterlaksanaan program, (b) mengetahui keberhasilan program, (c) mendapatkan bahan/masukan dalam perencanaan tahun berikutnya, dan (d) memberikan penilaian (judgement) terhadap sekolah/ madarasah ${ }^{8}$.

Pada dasarnya monitoring dan evaluasi adalah suatu kegiatan yang ditujukan untuk mengetahui dan menilai perkembangan ketercapaian dan kesesuaian antara Standar Kompetensi Lulusan dan lulusan dari masing-masing satuan pendidikan dan kurikulum yang digunakan pada satuan pendidikan tertentu secara berkala dan berkelanjutan dalam setiap periode, apakah sudah sesuai dengan rencana, program, dan/atau standar yang telah ditetapkan, serta menemukan hambatan-hambatan yang harus diatasi dalam implementasi program.

\footnotetext{
6 Ibid, hlm. 3.

7 Oteng Fattah, Administrasi dan Supervisi Pendidikan. (Jakarta: Bina Aksara, 2011), hlm. 102.

8 Departemen Pendidikan Nasional. Pedoman Supervisi Pengajaran. (Jakarta: Ditjen Dikdasmen, 2009), hlm. 21.
}

Pada satuan pendidikan di sekolah/madrasah monitoring dan evaluasi lebih berpusat pada pengontrolan dan penilaian selama program berjalan dan lebih bersifat klinis. Melalui monitoring dan evaluasi, dapat diperoleh umpan balik bagi sekolah/madrasah atau pihak lain yang terkait untuk menyukseskan ketercapaian tujuan standar kompetensi lulusan. Aspek-aspek yang dicermati dalam monitoring dan evaluasi adalah hal-hal yang dikembangan dan dijalankan dalam Rencana Pengembangan Sekolah (RPS). Dalam melakukan monitoring dan evaluasi ini tentunya kepala madrasah harus melengkapi diri dengan parangkat atau daftar isian yang memuat seluruh indikator standar kompetensi lulusan yang harus diamati dan dinilai.

Faktor-faktor pendukung Implementasi Permenag No. 2 Tahun 2008 dan Permendikbud Nomor 20 tahun 2016 tentang Standar Kompetensi Lulusan di MAN Prambon Nganjuk adalah: Kondisi riil standar isi dari standar proses, standar penilaian pendidikan, standar pendidik dan tenaga kependidikan, standar sarana dan prasarana, standar pengelolaan, dan standar pembiayaan sudah berjalan dengan baik dan memenuhi standar.

a. 1) Respon semua guru sangat baik dan mendukung, 2) Respon komite sangat baik dan mendukung, 3) Respon siswa sangat baik yang disertai dengan dukungan sikap, pengetahuan dan keterampilan siswa yang apresiatif selama mengikuti proses pembelajaran.

b. 1) Penerapan disiplin terhadap siswa sangat tinggi karena adanya nilai poin pelanggaran dan adanya pelayanan dan penanganan terhadap siswa yang bermasalah, 2) Hubungan madrasah dengan wali murid selalu dijaga dengan baik melalui pertemuan wali murid dengan pihak madrasah untuk membahas program-program madrasah dan kepentingan siswa, 3) Masalah pembiayaan sangat transparan dan adanya bantuan siswa miskin yang dilaksanakan secara berkala dan berkelanjutan yang sangat meringankan 


\section{intëlëktuãl \\ Jurnal Pendidikan dan Studi Keislaman}

beban orang tua/wali murid, 4) proses pembelajaran sudah sangat baik.

c. 1) Proses pembelajaran menyenangkan karena guru menggunakan variasi metode, 2) Adanya kemudahan dalam meminjam buku di perpustakaan, 3) Adanya program remidi bagi siswa yang berprestasi rendah, 4) adanya tugastugas yang menantang aktivitas dan kreativitas siswa.

Sementara itu faktor penghambatnya antara lain:

a. 1) Pengisian nilai raport untuk K-13 cukup rumit dan membutuhkan waktu waktu yang lama, 2) Jika guru ada kegiatan lain misalnya MGMP, proses pembelajaran kurang maksimal karena siswa hanya diberi tugas atau PR, 3) Tidak semua guru membuat program remidi dan pengayaan bagi seluruh siswa, sehingga SKL siswa tidak sempurna tingkat keobjektifannya 4) Untuk lab bahasa kurang maksimal, dan untuk lab TIK juga belum maksimal karena ada beberapa komputer yang rusak, sehingga sangat mengganggu pencapaian kompetensi berbahasa dan kemampuan mengoperasionalkan komputer 5) Biaya untuk lomba-lomba akademik siswa baik di tingkat Kabupaten maupun Propinsi belum maksimal karena keterbatasan anggaran

b. 1) sarana dan prasarana terutama lapangan olahraga bola voli, bola basket, lompat jauh, tenis meja kurang maksimal, dan perlu adanya perbaikan dan penyempurnaan, 2) seringnya kegiatan ekstrakurikuler pramuka menjadikan orang tua was-was terhadap masalah fisik dan psikis anak, terutama pada kegiatan gastra, dan lomba pramuka di berbagai daerah, 3) belum maksimalnya bimbingan belajar mapel matematika, biologi, kimia dan fisika menyebabkan kemampuan anak kurang maksimal dalam memahaminya, 4) SKU (syarat kecakapan ubudiyah) yang merupakan syarat wajib untuk lulus bagi siswa cukup memberatkan terutama bagi siswa yang kurang pandai dalam hal agama karena berasal dari tamatan sekolah umum (SMP), 5) banyaknya PR yang bertumpuk-tumpuk dari beberapa mata pelajaran menjadikan anak stress dan bingung

c. 1) belum maksimalnya les di madrasah, terutama mapel yang diujikan secara nasional, 2) syarat kecakapan ubudiyah yang seringkali memberatkan karena banyaknya hafalan yang wajib dikuasai siswa, padahal tidak semua siswa mampu manghafalnya dengan baik.

Tolak ukur keberhasilan implementasi kedua permen, faktor kendala, dan cara memecahkan faktor kendala yang terjadi antara lain:

a. Tolak ukur keberhasilan dari implementasi kedua permen tersebut antara lain: keberhasilan dan ketercapaian kompetensi inti dan kompetensi dasar masing-masing materi yang dikembangkan dalam kurikulum yang dapat dilihat dari pencapaian nilai kognitif, afektif dan psikomotor siswa. Untuk nilai kognitif dapat dilihat dari tinggi rendahnya nilai tugas, nilai ulangan harian, nilai mid semester, nilai semester, nilai try out, nilai ujian madrasah, nilai ujian nasional, nilai raport, dan nilai ijasah. Untuk nilai afektif siswa dapat diukur dari hasil observasi guru selama melakukan proses pembelajaran, terutama pada aspek minat, dan sikap serta kedisiplinan. Sedangkan untuk nilai psikomotor siswa dapat diukur dari hasil penilaian kegiatan praktek.

b. Faktor kendala yang muncul antara lain tidak semua siswa menyukai atau berminat mempelajari materi pelajaran, sebagian siswa merasa kesulitan dalam menyerap dan memahami materi pelajaran, siswa kurang berdisiplin, dan ramai selama proses pembelajaran, hasil belajar siswa banyak yang di bawah KKM, melanggar tata tertib, kemampuan praktek berbahasa Arab rendah dan kurang komunikatif, banyak yang mengabaikan keutamaan menjalankan praktek keagamaan, misalnya banyak siswa yang tidak melakukan sholat 
berjamaah, banyak siswa yang kurang mampu menghafal doa-doa dan membada al-Quran.

c. Cara untuk memecahkan faktor kendala yang terjadi selama ini adalah dengan cara mengadakan program remidi bagi siswa yang berprestasi rendah dan pengayaan bagi siswa yang berprestasi tinggi, membimbing siswa dalam kegiatan praktek berbahasa Arab dan keagamaan, mengentaskan masalah siswa yang melanggar tata tertib dengan meminta bantuan guru BK dan wali kelas, mengajak siswa untuk melakukan sholat berjamaah, membimbing siswa dalam menghafal doa-doa dan membaca al-Quran.

\section{Metode Penelitian}

Sementara itu jenis penelitian ini adalah penelitian deskriptif, yaitu penelitian yang berusaha untuk menuturkan pemecahan masalah yang ada sekarang berdasarkan data-data. Penelitian deskriptif dimaksudkan untuk mengumpulkan informasi mengenai status suatu gejala yang ada, yaitu keadaan gejala menurut apa adanya pada saat penelitian dilakukan.

Alasan peneliti menggunakan pendekatan penelitian kualitatif karena: penelitian ini berusaha menyajikan langsung hakikat hubungan antara peneliti dan responden dengan tujuan supaya lebih peka dalam menyesuaikan diri terhadap pola-pola nilai yang dihadapi ketika di lapangan sehingga memudahkan pengumpulan data tentang Implementasi Permenag No. 2 Tahun 2008 dan Permendikbud Nomor 20 tahun 2016 tentang Standar Kompetensi Lulusan di MAN Prambon Nganjuk.

\section{Hasil Penelitian}

Bentuk Implementasi Permenag No. 2 Tahun 2008 dan Permendikbud Nomor 20 tahun 2016

Implementasi Permenag No. 2 Tahun 2008 dan Permendikbud Nomor 20 tahun 2016 tentang Standar Kompetensi Lulusan di MAN Prambon Nganjuk (yang mengacu pada Standar Nasional Pendidikan dan
Permenag No. 2 Tahun 2008 bagi guru PAI dan Bahasa Arab) dapat berjalan dengan baik, maka: a. Guru dalam melaksanakan kegiatan pembelajaran harus menerapkan strategi dan metode tertentu, melaksanakan penilaian dan evaluasi, remidi dan pengayaan, serta menetapkan kualifikasi kemampuan lulusan yang mencakup sikap, pengetahuan, dan keterampilan peserta didik yang harus dipenuhinya atau dicapainya. b. Dalam penerimaan siswa baru guru harus mengadakan tes peminatan dengan cara mengadakan tes tulis, menyebarkan angket dan wawancara yang hasilnya digunakan untuk menempatkan siswa pada program penjurusan yang sesuai, yaitu: IPA, IPS atau Agama. Sedangkan untuk siswa kelas XI dan XII dengan cara guru harus mengadakan pembelajaran (kurikuler), mengadakan penilaian terhadap proses dan hasil pembelajaran, mengadakan evaluasi hasil belajar, mengadakan program remidi dan pengayaan, mengadakan kegiatan ekstra kurikuler, dan pembiasaan yang berupa hafalan al-Quran, dan doa-doa.

\section{Implikasi dari Implementasi Permenag Nomor 2 Tahun 2008 dan Permendiknas Nomor 20 tahun 2016}

Agar implikasi dari implementasi Permenag No. 2 Tahun 2008 dan Permendikbud Nomor 20 tahun 2016 tentang Standar Kompetensi Lulusan di MAN Prambon Nganjuk dapat dilaksanakan sesuai dengan prosedur dan tujuan, maka: pertama, Implikasinya harus didasarkan pada tujuan pendidikan nasional yang digunakan sebagai acuan pengembangan standar isi, standar proses, standar penilaian pendidikan, standar pendidik dan tenaga kependidikan, standar sarana dan prasarana, standar pengelolaan, dan standar pembiayaan.

Kedua, Implikasinya harus didasarkan pada ruang lingkup standar kompetensi lulusan, yaitu sesuai dengan kriteria kualifikasi kemampuan peserta didik yang diharapkan dapat dicapai setelah menyelesaikan masa belajarnya di madrasah. 
a. Implikasinya harus dilakukan dengan cara mengadakan monitoring dan evaluasi melalui rapat-rapat dinas yang hasilnya selalu digunakan sebagai bahan masukan bagi penyempurnaan Standar Kompetensi Lulusan di masa yang akan datang,

b. Implikasinya harus dilaksanakan berdasar kebijakan kepala madrasah untuk menetapkan dan menilai kualifikasi kemampuan lulusan yang mencakup sikap, pengetahuan, dan keterampilan peserta didik yang harus dipenuhinya atau dicapainya ketika belajar di madrasah dengan selalu memperhatikan: 1) perkembangan psikologis anak; 2) lingkup dan kedalaman; 3) kesinambungan; 4) fungsi satuan pendidikan; dan 5) lingkungan madrasah.

c. Implikasinya harus dijalankan dengan baik sesuai dengan rencana

\section{Faktor Pendukung dan Penghambat}

Agar faktor pendukung

Implementasi Permenag No. 2 Tahun 2008

dan Permendikbud Nomor 20 tahun 2016 tentang Standar Kompetensi Lulusan di MAN Prambon Nganjuk dapat dioptimalkan, maka: pertama, kondisi riil standar isi dari standar proses, standar penilaian pendidikan, standar pendidik dan tenaga kependidikan, standar sarana dan prasarana, standar pengelolaan, dan standar pembiayaan harus dimaksimalkan dan memenuhi standar yang telah ditetapkan. Kedua.,respon semua guru harus positif dan mendukung pencapaian standar kompetensi lulusan, 2) Respon komite harus dimaksimalkan, 3) Respon siswa harus maksimal yang disertai dengan dukungan sikap, pengetahuan dan keterampilan siswa yang apresiatif selama mengikuti proses pembelajaran, ketiga,1) Penerapan disiplin terhadap siswa harus dimaksimalkan dengan menerapkan nilai poin pelanggaran sesuai ketentuan dan pelayanan dan penanganan terhadap siswa yang bermasalah dimaksimalkan, 2) Hubungan madrasah dengan wali murid harus selalu dijaga dengan baik melalui pertemuan wali murid dengan pihak madrasah untuk membahas programprogram madrasah dan kepentingan siswa, 3) pembiayaan yang dibebankan kepada wali murid harus transparan dan bantuan siswa miskin harus dilaksanakan secara berkala dan berkelanjutan agar meringankan beban orang tua/wali murid, 4) proses pembelajaran harus ditingkatkan kualitasnya. Keempat, 1) Proses pembelajaran dari semua guru harus menyenangkan dengan menggunakan variasi metode, 2) Siswa harus dimudahkan dalam meminjam buku di perpustakaan, 3) Program remidi bagi siswa yang berprestasi rendah harus dimaksimalkan, 4) tugas-tugas yang menantang aktivitas dan kreativitas siswa harus dimaksimalkan.

Agar faktor-faktor Penghambat Implementasi Permenag No. 2 Tahun 2008 dan Permendikbud Nomor 20 tahun 2016 tentang Standar Kompetensi Lulusan di MAN Prambon Nganjuk dapat diminimalkan, maka:

a. 1) Pengisian nilai raport untuk K-13 menggunakan aplikasi harus dibantu oleh petugas khusus dari bagian TU agar prosesnya cepat, 2) Jika guru ada kegiatan lain misalnya MGMP, maka pemberian tugas atau PR harus diawasi oleh guru piket, 3) Semua guru harus membuat program remidi dan pengayaan bagi seluruh siswa, sehingga SKL siswa menjadi sempurna dan objektif 4) Untuk lab bahasa, dan untuk lab TIK harus dimaksimalkan penggunaannya agar kemampuan siswa dalam menguasai kompetensi bahasa maksimal dan kemampuan siswa dalam mengoperasionalkan komputer juga maksimal 5) Biaya untuk lomba-lomba akademik siswa baik di tingkat Kabupaten maupun Propinsi harus dimaksimalkan sesuai dengan kemampuan anggaran

b. 1) sarana dan prasarana terutama lapangan olahraga bola voli, bola basket, lompat jauh, tenis meja harus dimaksimalkan peruntukannya, dan perlu adanya perbaikan dan penyempurnaan, 2) Orang tua harus 
memberikan dukungan kepada siswa agar mengikuti kegiatan ekstrakurikuler pramuka, siswa harus menjaga fisik dan psikis, terutama pada kegiatan gastra, dan lomba pramuka di berbagai daerah, 3) guru harus memaksimalkan bimbingan belajar mapel matematika, biologi, kimia dan fisika agar kemampuan anak maksimal dalam memahaminya, 4) SKU (syarat kecakapan ubudiyah) yang merupakan syarat wajib untuk lulus bagi siswa harus tidak lagi menjadi beban yang memberatkan terutama bagi siswa yang kurang pandai dalam hal agama walaupun sebagian siswa berasal dari tamatan sekolah umum (SMP) dengan cara memberikan bimbingan yang komprehensif dan pengecekan hafalan secara berkala sesuai dengan jadwal, 5) walaupun PR bertumpuk-tumpuk dari beberapa mata pelajaran, maka anak harus diperhatikan dan dibimbing agar mereka mampu mengerjakan dengan baik sehingga menjadikan anak tidak stress dan tidak bingung

c. 1) guru harus memaksimalnkan les di madrasah, terutama mapel yang diujikan secara nasional, 2) syarat kecakapan ubudiyah tidak harus memberatkan tetapi malah menyenangkan siswa walaupun banyaknya hafalan yang wajib dikuasai siswa, namun semua siswa harus mampu manghafalnya dengan baik dengan cara semua pembimbing dan guru PAI membantu dan membimbing siswa dengan baik sampai tuntas.

Agar tolak ukur keberhasilan implementasi kedua permen menjadi jelas, faktor kendala dapat diidentifikasi, dan cara memecahkan faktor kendala yang terjadi dapat dilaksanakan dengan baik, maka:

a. Keberhasilan dan ketercapaian kompetensi inti dan kompetensi dasar masing-masing materi yang dikembangkan dalam kurikulum harus didasarkan pada pencapaian nilai kognitif, afektif dan psikomotor siswa. Untuk nilai kognitif harus didasarkan pada tinggi rendahnya nilai tugas, nilai ulangan harian, nilai mid semester, nilai semester, nilai try out, nilai ujian madrasah, nilai ujian nasional, nilai raport, dan nilai ijasah. Untuk nilai afektif siswa harus didasarkan pada hasil observasi guru selama melakukan proses pembelajaran, terutama pada aspek minat, dan sikap serta kedisiplinan. Sedangkan untuk nilai psikomotor siswa harus didasarkan pada hasil penilaian kegiatan praktek.

b. Faktor-faktor kendala yang muncul dapat dipecahkan dengan baik, dengan cara guru harus mampu memberikan motivasi agar siswa menyukai atau berminat mempelajari materi pelajaran, siswa tidak mengalami kesulitan dalam menyerap dan memahami materi pelajaran, siswa menjadi berdisiplin, dan tidak ramai selama proses pembelajaran, hasil belajar siswa banyak yang di atas KKM, siswa tidak lagi melanggar tata tertib, kemampuan praktek berbahasa Arab tinggi dan maksimal, serta komunikatif, banyak siswa melaksanakan keutamaan menjalankan praktek keagamaan, misalnya dalam melakukan sholat berjamaah, menghafal doa-doa dan membada al-Quran, dan semua guru mampu mengidentifikasi semua faktor tersebut dengan baik.

c. Cara untuk memecahkan faktor kendala dimaksimalkan dengan cara guru harus melakukan program remidi bagi siswa yang berprestasi rendah dan pengayaan bagi siswa yang berprestasi tinggi dilaksanakan secara berkesinambungan, melaku-kan pembimbingan kepada seluruh siswa dalam kegiatan praktek berbahasa Arab dan keagamaan, mengentaskan masalah siswa yang melanggar tata tertib dengan meminta bantuan guru BK dan wali kelas dilakukan dengan cara yang prosedural dan maksimal, mengajak siswa untuk melakukan sholat berjamaah, membimbing siswa dalam menghafal doa-doa dan membaca al-Quran.

Implikasi dari temuan tersebut harus digunakan semaksimal mungkin oleh 
madrasah dan pihak-pihak terkait (seluruh komponen madrasah) terutama dalam hal: pertama, Perbaikan standar isi: kurikulum (KTSP) dan K-13 harus mampu dilaksanakan secara maksimal karena kedalaman muatan kurikulum yang dituangkan dalam kompetensi (standar kompetensi dan kompetensi dasar) pada setiap tingkat dan/atau semester, beban belajar, jam pembelajaran, waktu efektif tatap muka, dan persentase beban belajar setiap kelompok mata pelajaran harus dapat dilaksanakan sesuai dengan rencana.

Kedua, Perbaikan standar proses: proses pembelajaran harus diselenggarakan secara interaktif, inspiratif, menyenangkan, dan menantang, serta memaksimalkan peran motivasi bagi peserta didik untuk berpartisipasi aktif dalam pembelajaran, dengan cara metode pembelajaran yang diterapkan guru adalah metode kooperatif (Paikemi: pembelajaran yang aktif, inovatif, kreatif, efektif dan menyenangkan serta islami), memaksimalkan perencanaan pembelajaran, pelaksanaan proses pembelajaran, penilaian hasil pembelajaran, dan pengawasan proses pembelajaran agar proses pembelajaran yang efektif dan efisien tercipta dengan baik.

Ketiga,Perbaikan standar pendidik: kualifikasi akademik yang dibuktikan dengan ijazah dan/atau sertifikat keahlian semuanya relevan sesuai ketentuan per undang-undangan yang berlaku, dan kompetensi guru sebagai agen pembelajaran yang meliputi kompetensi pedagogik; kompetensi kepribadian; kompetensi profesional; dan kompetensi sosial dimaksimalkan.

Kelima, perbaikan standar sarana dan prasarana: sarana terutama perabot, peralatan pendidikan, media pendidikan, buku dan sumber belajar lainnya, harus terpenuhi dengan baik dan maksimal, prasarana terutama lahan, ruang kelas, ruang pendidik, ruang tata usaha, ruang perpustakaan, ruang laboratorium, tempat berolahraga, tempat beribadah, tempat bermain, tempat berkreasi, dan ruang/tempat lain yang diperlukan untuk menunjang proses pembelajaran yang teratur dan berkelanjutan harus terpenuhi dengan baik dan dimaksimalkan.

\section{Kesimpulan}

Bentuk Implementasi Permenag No. 2 Tahun 2008 dan Permendikbud Nomor 20 tahun 2016 tentang Standar Kompetensi Lulusan di MAN Prambon Nganjuk (yang mengacu pada Standar Nasional Pendidikan dan Permenag No. 2 Tahun 2008 bagi guru PAI dan Bahasa Arab) adalah berikut: pertama, Guru melaksanakan kegiatan pembelajaran dengan menerapkan strategi dan metode mengajar yang sesuai, mengadakan penilaian dan analisis hasil belajar, serta evaluasi, mengadakan program remidi dan pengayaan, kedua, Pengadaan tes peminatan pada siwa baru untuk penempatan jurusan.

Implikasi dari Implementasi

Permenag Nomor 2 Tahun 2008 dan Permendiknas Nomor 20 tahun 2016 Tentang Standar Kompetensi Lulusan di MAN Prambon Nganjuk adalah berikut:, Implikasinya didasarkan pada pada tujuan pendidikan nasional yang digunakan sebagai acuan pengembangan standar isi, standar proses, standar penilaian pendidikan, standar pendidik dan tenaga kependidikan, standar sarana dan prasarana, standar pengelolaan, dan standar pembiayaan. Implikasinya didasarkan pada ruang lingkup standar kompetensi lulusan, yaitu sesuai dengan kriteria kualifikasi kemampuan peserta didik yang diharapkan dapat dicapai setelah menyelesaikan masa belajarnya di madrasah. Implikasinya dilakukan dengan cara mengadakan monitoring dan evaluasi. Implikasinya dilaksanakan berdasar kebijakan kepala madrasah untuk menetapkan dan menilai kualifikasi kemampuan lulusan yang mencakup sikap, pengetahuan, dan keterampilan peserta didik. Implikasinya dijalankan dengan baik sesuai dengan rencana

Faktor-faktor Pendukung dan Penghambat Implementasi Permenag Nomor 2 Tahun 2008 dan Permendikbud Nomor 20 tahun 2016 tentang Standar 
Kompetensi Lulusan di MAN Prambon Nganjuk adalah berikut:

Faktor-faktor

Pendukung

Implementasi Permenag No. 2 Tahun 2008 dan Permendikbud Nomor 20 tahun 2016 tentang Standar Kompetensi Lulusan di MAN Prambon Nganjuk adalah sangat bervariasi, antara lain: Faktor-faktor Pendukung antara lain: a) Kondisi riil standar isi yang bagusdan Respon komite dan siswa sangat baik. Sedangkan faktorfaktor penghambatnya antara lain: fasilitas untuk memenuhi terlaksnanya kurikulum 13 sangat terbatas.

\section{Daftar Pustaka}

Arikunto, S. (2006), Prosedur Penelitian Suatu Pendekatan Praktek (Jakarta: Rineka Cipta, 2006).

Arikunto,S. Suhardjono, dan Supardi, Penelitian Tindakan Kelas (Jakarta: Bumi Aksara, 2008).

Ary, Donald, dkk. Introduction to Research In Education. Penerjemah Arief Furchan, Pengantar Penelitian dalam Pendidikan (Surabaya: Usaha Nasional, 1982).

Benny A. Pribadi, , Model Desain Sistem Pembelajaran (Jakarta: Dian Rakyat, 2009).

Direktorat Madrasah dan Pendidikan Agama Islam (PAI) pada Sekolah Umum, Pedoman Integrasi Life Skills dalam Pembelajaran Madrasan Aliyah, (Jakarta: Depag RI, 2005).

Faisal, Sanafiah. Metodologi Penelitian Pendidikan (Surabaya: Usaha Nasional, 1982).

Firdaus, dan Hanafi, Penyelenggaraan Wajar Dikdas Sembilan Tahun 2004 2010 (Jakarta: Ditjen Pendidikan Islam Kementerian Agama RI).

Ghozali, A. dan Fuaduddin, Kepemimpinan Kepala Madrasah yang Efektif (Jakarta: Depag RI Balai Diklat Keagamaan Pusdiklat Administrasi, 2005).

Hamalik, Oemar, Psikologi Belajar Mengajar (Jakarta: Sinar Baru Algensindo, 2002).
Handoko, Manajemen Edisi II (Yogyakarta: BPFE, 1996).

Kundandar, Langkah Mudah Penelitian Tindakan Kelas sebagai Pengembangan Profesi Guru (Jakarta: Raja Grafindo Persada, 2008).

Mappiare, AAT, Dasar-dasar Metodologi Riset Kualitatif, (Malang: Jenggala Pustaka Utama, bersama Fakultas Ilmu Pendidikan Universitas Negeri Malang, 2009).

Moleong, LJ., Metodologi Penelitian Kualitatif. (Bandung: Remaja Rosdakarya, 2006).

Mulyana, D., Metodologi Penelitian Kualitatif: Paradigma Baru Ilmu Komunikasi dan Ilmu Sosial lainnya (Bandung: Remaja Rosydakarya, 2001).

Mulyasa, E., Kurikulum Berbasis Kompetensi, Konsep, Karakteristik, dan Implementasi (Jakarta: Bumi Aksara, 2003).

Mulyasa, E., Implementasi Kurikulum Tingkat Satuan Pendidikan Kemandirian Guru dan Kepala Sekolah (Jakarta: Bumi Aksara, 2008).

Narbuko, C dan Achmadi, A., Metodologi Penelitian (Jakarta: Bumi Aksara, 2002).

Nasution, Metode Penelitian NaturalistikKualitatif, (Bandung: Tarsito, 1988).

Paraba, H., Wawasan Tugas Tenaga Guru dan Pembina Pendidikan Agama Islam, (Jakarta: Friska Agung Insani, 2000).

Permendikbud Nomor 20 tahun 2016 tentang Standar Kompetensi Lulusan untuk Satuan Pendidikan Dasar dan Menengah (Jakarta, BNSP, 2005).

Permendikbud Nomor 20 tahun 2016 Tentang Standar Kompetensi Lulusan (Jakarta: Biro Hukum dan Organisasi, 2006).

Permenag No. 2 Tahun 2008 tentang Standar Kompetensi Lulusan Untuk Mapel PAI dan Bahasa Arab (Jakarta: Kementerian Agama RI, 2008). 
Riduan, Metode dan Teknik Penyusunan Tesis (Bandung: Alfabeta, 2006).

Riyadi, S., Metodologi Penelitian (Surabaya: Fakultas Ekonomi Universitas Dr. Soetomo, 1997).

Sudjana, Metode Statistika, (Tarsito: Bandung, 2005).

Sugiyono, Memahami Penelitian Kualitatif (Bandung: CV. Alfabeta, 2005).

Sugiyono, Metode Penelitian Pendidikan. Pendekatan Kuantitatif, Kualitatif, dan $R \& D$, (Bandung: Alfabeta, 2008).

Surachmad, Winarno, Dasar dan Tehnik Research (Bandung: Tarsito, 1978).

Suryabrata, Sumadi, Metodologi Penelitian (Jakarta: Rajawali Press, 1990).

Tarsa, HM., Basic Kompetensi Guru (Jakarta: Proyek Pembinaan Calon Tenaga Kependidikan Biro Kepegawaian Setjen Depag RI, 2003).

Tim Direktorat Jenderal Kelembagaan Agama Islam, Kendali Mutu Pendidikan Agama Islam (Jakarta: Depag RI Direktorat Jenderal Kelembagaan Agama Islam, 2003).

Tim Dirjen Pendidikan Madrasah Direktorat Jenderal Pendidikan Islam Kementerian Agamar RI, (2010), Modul Pelatihan Penjaminan dan Pengendalian Mutu Pendidikan Madrasah, Jakarta: Kementerian Agama RI, 2010).

Tim Pembina Mata Kuliah. (2001), Perencanaan, Implementasi dan Evaluasi Kebijakan Publik (Surabaya: Puslitabmas Universitas Wijaya Putra, 2001).

Tim Penyusun, (2006), Panduan Penulisan dan Penilaian Skripsi. (Surabaya: Universitas Negeri Surabaya, 2006).

Tarsa, HM. (2003), Basic Kompetensi Guru Uakarta: Proyek Pembinaan Calon Tenaga Kependidikan Biro Kepegawaian Setjen Depag RI, 2003).

Tim Direktorat Jenderal Pembinaan Kelembagaan Agama Islam/Direktorat Pembinaan Pendidikan Agama Islam pada Sekolah Umum, (2011), Metodologi Pendidikan Agama Islam, (Jakarta:
Direktorat Jenderal Pembinaan

Kelembagaan

Agama

Islam/Direktorat Pembinaan

Pendidikan Agama Islam pada Sekolah Umum melalui Bagian Proyek Peningkatan Tenaga Teknis Pendidikan Agama Islam, 2011).

Tim Direktorat Jenderal Kelembagaan Agama Islam, Kendali Mutu Pendidikan Agama Islam (Jakarta: Depag RI Direktorat Jenderal Kelembagaan Agama Islam, 2003).

Tim Dirjen Pendidikan Madrasah Direktorat Jenderal Pendidikan Islam Kementerian Agamar RI, (2010), Modul Pelatihan Penjaminan dan Pengendalian Mutu Pendidikan Madrasah, (Jakarta: Kementerian Agama RI, 2010).

Tim Pembina Mata Kuliah.(2001), Perencanaan, Implementasi dan Evaluasi Kebijakan Publik (Surabaya: Puslitabmas Universitas Wijaya Putra, 2001).

Tim Penyusun, (2006), Panduan Penulisan dan Penilaian Skripsi. (Surabaya: Universitas Negeri Surabaya, 2006)

Widuroyekti, Barokah, (2008), Optimalisasi Kinerja Guru dalam Menciptakan Sekolah yang Efektif dalam MPA 259. (Surabaya: Kanwil Depag Jawa Timur, 2008).

Wijayanti, Peningkatan Mutu Pendidikan dalam MPA 250, Juli 2007.

(Surabaya: Kanwil Depag Propinsi Jawa Timur).

Zayadi, A. dan Aziz, AA., Desain Pengembangan Madrasah (Jakarta: Depag RI Direktorat Jenderal Kelembagaan Agama Islam, 2004). 